\title{
Kenti Yaşayandan Öğrenmek: Şehircilik Çalıșmalarında Rehberli Gezi Yönteminin Kullanımı, İzmir-Selçuk ve Bursa-İznik Örnekleri
}

\author{
Learning the City from the Inhabitants: Application of the Commented Walk \\ Method in Urban Studies, Izmir - Selcuk and Bursa - Iznik Examples
}

\author{
Gizem AKSÜMER
}

ÖZ

Bu makale, 2015 Mayıs ayında İzmir Selçuk'ta ve 2016 Eylül ayında ise Bursa İznik'te gerçekleştirilen araştırmalara dayanmaktadır. Araştırmalarda nicel bir yöntem olan kartografik yeniden çizim ile rehberli gezi yöntemi birlikte kullanılarak kentlerdeki değişim irdelenmiştir. İki yöntem birlikte kullanılırken, rehberli gezi yönteminin şehircilik alanında hiç kullanılmıyor olması, buna karşın kentsel değişimin saptandığı bu araştırmaya çok önemli katkılar yapmış olması gibi sebeplerle bu yöntemin makale kapsamında ayrıntılı olarak ortaya konması hedeflenmiştir. Dolayısıyla bu makalenin amacı, rehberli gezi yönteminin şehircilik çalışmalarındaki yerini tartışmaya açmak, yöntemin hangi temaları öne çıkardığını, kentin değişimini anlamak konusunda nasıl fayda sağladığını ortaya koyarak literatüre katkı sağlamaktır. Dolayısıyla bu makale, kentlerin yıllar içindeki değişiminin nasıl olduğunu dönemlere ayırarak anlatmak yerine, rehberli gezi yönteminin bu araştırmalarda nasıl kullanıldığını, yöntemin şehirciliğe katkısını tartışmayı amaçlamaktadır. Makale boyunca, araştırmalarda öncelikle nicel yöntem sayesinde elde edilen sonuç bulguları özet biçimde irdelenmiş, böylece kentlerin nasıl dönüştükleri ayrıntılı olarak ortaya konmuştur. Ardından makalenin temel konusu olan rehberli gezi yönteminin araştırma sürecinde hangi tematik başlıkları karşımıza çıkardığı tartışılmış, bulgulara değinilmiş ve sonuçta bu yöntemin kentlerin değişimini anlamaya çalışan bir araştırmada ne gibi katkılar sağladığı ortaya konmuştur.

Anahtar sözcükler: Gezici yöntemler; İnik; kentsel çalışmalar; rehberli gezi; şehircilikte yöntem; Selçuk.

\section{ABSTRACT}

This article is based on the researches carried out in Izmir Selçuk in May 2015 and in Bursa İnik in September 2016. Cartographic redrawing method, which is a quantitative method, and commented walk method were used together in the researches to examine the change of cities. While the two methods are used together, it is aimed to examine the consequences of the commented walk method in detail due to the fact that this method is never used in the field of urbanism, however, it has made significant contributions to the researches. Therefore, the aim of this article is to discuss the place of commented walk method in urban studies, to contribute to the literature by revealing which themes the method brings to the fore and how it benefits to understand the change of the city. This article aims to discuss how the commented walk method is used in these researches and the contribution of this method to urbanism instead of explaining the change of cities over the years. Throughout the article, first of all, the findings obtained through quantitative methods have been examined and the transformation of the cities has been explained in detail. Then, the thematic headings of the commented walk method, which is the main subject of the article, is revealed, the findings are discussed and as a result, the contribution of this method in a research that tries to understand the change of cities is revealed.

Keywords: Mobile methodologies; Iznik; urban studies; commented walk; methodologies in urban studies; Selçuk.

Mimar Sinan Güzel Sanatlar Üniversitesi, Şehir ve Bölge Planlama Bölümü, İstanbul 


\section{Giriş}

Sosyolojiden antropolojiye, jeolojiden peyzaja pek çok farklı disiplinden alınan yöntemler, şehircilik çalışmalarında kullanılmaktadır. Büyük verilerin işlendiği, üst ölçekten kentsel mekânın okunabildiği niceliksel yöntemlerin dışında; kent kullanıcılarını odağına alan yöntemler teknolojik olanaklardan da faydalanarak gelişmiştir. Bir yandan bütüne hâkim olmak isteyen ve büyük kent parçaları arasındaki ilişkiyi sorgulayan coğrafya ve şehircilik, Fuller ve Kitchin'in ${ }^{1}$ belirttiği gibi bir "katılımcı dönüş" yaşamaya başlamıştır. Bu sayede toplum bileşenlerini ve algılarını da araştırmaya ekleyen niteliksel çalışmalar yapılmaya başlanmıştır.

Bu makalenin odağında olan ve kentin nasıl dönüştüğünü anlamak için iki farklı saha araştırmasında kartografik yeniden çizim metoduyla birlikte etkin biçimde kullanılan "rehberli gezi yöntemi"2 ise "gezici yöntemler"3 içerisinde yer alır ve fiziksel mekân ile söylemin kesişimini sağlar. Rehberli gezi ve içinde yer aldığı gezici yöntemler literatürü uluslararası akademik camiada temel paradigmaları dönüştürücü teorik tartışmalara sahne olmuş, kentsel çalışmalarda da etkin biçimde kullanılmaya başlanmıştr. ${ }^{4}$ Gezici yöntemlere ilişkin ise, Türkiye literatüründe, psikocoğrafya ${ }^{5}$ ve kent sosyolojisi ${ }^{6}$ alanlarında olmak üzere çok az sayıda çalışma yapılmış olsa da, kentin mekânsal değişimini, sınırlarını, fonksiyonlarını anlama hedefindeki çalışmalar gerçekleştirilmemiştir. Bu makalede alt çizilen ve Thibaud, Petitetau ile Pasquier ${ }^{7}$ tarafindan geliştirilen rehberli gezi yöntemi ise şu ana kadar Türkiye şehircilik literatüründe hiç kullanılmamıştır. Bu bağlamda makalenin temel amacı, 2015 Mayıs ayında İzmir Selçuk'ta ve 2016 Eylül ayında ise Bursa İznik'te gerçekleştirilen, kentlerin nasıl dönüştüğünü anlamayı hedefleyen araşttrmalarda rehberli gezi yönteminin nasıl kullanıldığını, yöntemin hangi temaları bulmakta kolaylık sağladığını ve şehirciliğe katkısını ortaya koymaktır.

Selçuk'ta yapılan araştırmada rehberli gezi yalnızca kartografik yeniden çizimle ortaya çıkan veriyi yorumlamakta kullanılmak amacıyla kısıtlı tutulmuş, rehberli geziler yalnızca 11 kişi ile kent dolaşılarak gerçekleştirilmiştir. Ancak İznik kentinde rehberli gezi konusunda kazanılmış olan deneyim, morfolojik dönüşümleri saptamada yöntemin daha etkin kullanılabileceği kanısını oluşturduğu için 28 kişiyle ${ }^{8}$ daha uzun geziler yapılarak araştrma genişletilmiştir. Bu bağlamda iki araştırmada toplanabilen ayrıntılar ve kentsel yaşamın nasıl değiştiğine dair bilgilerin içerikleri çokça genişlemiş, rehberli gezinin daha yoğun kullanıldığı araştırmada veriler daha katmanlı bir hal alabilmiş, kent morfo-

\footnotetext{
Fuller ve Kitchin, 2004.

2 (pracours commentés - méthode des itineraires) Petiteau ve Pasquier, 2001,

Thibaud, 2001.

Mobile methodologies

4 Kusenbach, 2006; Carpiano, 2009.

Yeşil, 2016.
}

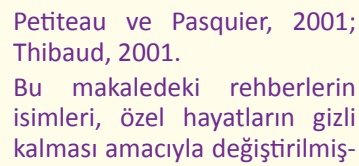

lojisi ile gündelik hayatın değişimi arasındaki bağ daha sıkı kurulmuştur. Iki araştırma arasındaki bu farklılaşma bize rehberli gezi yönteminin şehircilik çalışmalarında neden önemli olabileceği hakkında ipuçları vermektedir.

Bu bağlamda makalede öncelikle rehberli gezi yönteminin içinde bulunduğu gezici yöntemlerin hangi çalışmalar kapsamında, nasıl kullanıldıkları tartışılacaktır. İkinci bölümde, kartografik yeniden çizim yöntemiyle araştırmalardan elde edilen sonuçlarla kentlerin nasıl dönüştüğü, daha önce yazılan makale ${ }^{9}$ ve proje metnine ${ }^{10}$ referansla dönemlere göre ortaya konacaktır. Üçüncü olarak, yöntem için çok önemli olan araştırma kurgusunun iki farklı araştırmada nasıl oluşturulduğu, sahaya nasıl girildiği, rehberlerle karşılaşmaların nasıl gerçekleştiği ve iki araştırmada da karşımıza çıkan temel temalar görüşmelerin içeriği analiz edilerek ortaya konmuştur. Sonrasında, rehberli gezilerle kentin değişimi katılımcılara sorulduğunda iki araştırmada da ortak olarak karşımıza çıkan 4 temel tema altında bu değişimlerin algılandığı tespit edilmiştir. Kentin sınırları, kamusal mekânlar, toplumsal ilişkilerin dönüşümünün mekândaki iz düşümleri, parsel ve hatta bina gibi küçük ölçekteki fonksiyon değişiklikleri kentliler tarafindan en çok hissedilen, bu sebeple de dile getirilen değişiklikler olmuştur.

\section{Hareketli Yöntemler İçinde Rehberli Gezi}

Küçük ölçekli ve daha çok insan ilişkileri ya da kentteki toplumsal ağlar, gündelik yaşam pratikleri konusunda yapılan araştrmalarda genel olarak, derinlemesine görüşmeler, odak grup görüşmeleri, katılımcı gözlemler gibi klasikleşmiş teknikler kullanılmaktadır. Bu yaklaşımların da yeni dönemde dönüştükleri, post-modern literatürden etkilendikleri ve araştıran ile araştırmacı arasındaki ilişkiyi yapı bozumuna uğratmaya çalıştikları söylenebilir. ${ }^{11} \mathrm{Bu}$ bağlamda kent araştırmacısının bir "her şeyi bilen" olmadığı, araştırmanın katilımcılarla birlikte tasarlandığı ve hatta katılımcı eylem araştırmasında olduğu gibi uygulamanın da araştırma süreci ile birleştirildiği araştırmalar ortaya çıkmaktadır. ${ }^{12}$

Bu bağlamda, makalenin temel odağında olan rehberli gezi yöntemi kent sakinlerinin yaşadıkları mekânı nasıl algıladıklarını anlayabilmek için kullanılmıştı. Rehberli gezi yönteminin temel özellikleri şehircilik ve coğrafya çalışmalarında da kullanılan bazı temel yöntemsel yaklaşımla benzerlik göstermekte ve o yaklaşımlardan beslenmektedir. Bu yaklaşımlardan biri Kevin Lynch'in ${ }^{13}$ geliştirdiği, kentte yaşayanlarla birlikte oluşturulan algı haritaları yaklaşımıdır. Kevin Lynch ve ona benzer yöntemleri kullanan araştırmacılar, ${ }^{14}$ kentteki sorunların tespiti ya da kentteki değişimle-

\footnotetext{
Yücel ve Aksümer; 2018.

${ }^{10}$ Yücel, S.D., Aksümer, G., Seçer S. ${ }^{13}$ Lynch, 2010.

2018.

${ }^{11}$ Emerson, 2001; Borda, 2001; Denzin fim ve Urrutia, 2015; Gieseking, ve Lincoln, 2011; Irby vd., 2013.
} 
re odaklanmak yerine yalnızca kentin nasıl algılandığına ve farklı algılama biçimlerine bakmışlardır.

Rehberli gezi yöntemi aslen 2000'li yıllarda gündeme gelen "gezici yöntemler" literatürü içerisinde yer almaktadır. Pek çok farklı teknikle uygulanan bu yöntem, araştrrmaya konu olan kişilerle birlikte araştırma alanında dolaşarak yapılmaktadır.

KEA ile gündeme gelen araştırmanın öznelerini araştormaya katma fikri ${ }^{15}$ en yoğun biçimde gezici araştırmalar içinde kullanılır. Öncelikle gezici araştırmalar, özellikle yapılan görüşmelerin, içinde bulunulan mekândan çokça etkilendiği iddiasıyla ortaya çıkmıştır. Ingold ve Lee, ${ }^{16}$ yürüyerek yapılan görüşmelerin mekânla bağları güçlendirdiğini belirtmektedir. Bu bağlamda bu makalede de İznik ve Selçuk yürünerek araştrrma yapılmış hem araştırmacının hem araştırma öznesi kişilerin araştrrma sırasında mekânla daha güçlü bağlar kurması sağlanmıştir. Bu güçlü bağlar, kentin değişimine dair ayrıntıların hatılanmasını kolaylaştırmış, anlatıların betimleyiciliğini arttırmıştır.

Mekân ve görüşmecinin birbirinden etkilenmesi iddiasının bir adım daha ötesine geçen gezici araştırma yöntemlerindeki en temel özellik, araştırmayı yapan ve araştırmaya katılan kişilerin birlikte mekânda dolaşıyor olması ve araştırmanın dolaşarak yapılmasıdır. İkinci temel özellik ise, araştırmacının değil araştırmaya katılan kentlilerin rehberlik etmesi ve inisiyatifin büyük bölümünü onların alması olarak ortaya konabilir. Law ve Urry ${ }^{17}$ ise, gezici yöntemlerin ortaya çıkmasını, mevcuttaki araştırma yöntemlerinin pek çok konuda kısıtlı kalmasına bağlamaktadır. Yazarlar, ${ }^{18}$ mevcuttaki yöntemlerin 21. Yüzyılın gerçeklikleriyle örtüşmediğini, hızlı geçen zamanla, sürekli değişen mekânlarla ilişkilenemediğini eklerler. Bu anlamda Law ve Urry, yeni bir paradigmadan bahsetmiş olurlar; bu paradigma hareketli olana ve hareketin kendisi aracılığıyla bir araştırmaya dayanır. Urry, ${ }^{19} 21$. Yüzyılda artık geleneksel yöntemlerin bir kenara bırakılması gerektiğini, sosyolojinin kırılamaz kabuğunun yerine daha esnek bir biçime sahip olmasının toplumu daha iyi anlamak için yararlı olacağını anlatır. Haldrup, ${ }^{20}$ bir 'hareketlilik dönüşünde' olduğumuzu bildirir ve araştırmasında araştırma katılımcılarının tuttuğu zaman-mekân günlükleri aracılığıyla boş zamanlardaki hareketliliği inceler.

Kent çalışmalarında da bu hareketliliğin yer alması oldukça önemli bir yere sahip olmuştur. Özellikle kent sakini ve araştirmacı arasındaki ilişkiyi tamamen yeniden düşünen ve kentsel çalışmalarda yerini alan bir araştırma tekniği olarak da "gezici yöntemler" önem kazanır. ${ }^{21} \mathrm{Bu}$ tür yöntemlere ilişkin Lesley Murray ${ }^{22}$ öncelikle bir mekânın

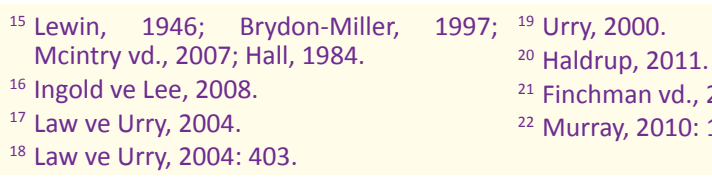

ancak başka bir mekânla ilişkili olarak anlaşılır kılınabileceğini belirtir. Bu noktada kentsel mekânın değişmeyen bir varlık olmadığı, deneyimlenerek yeni anlamlar kazandığı, farklı deneyimlerin kent okumasını da farklı kılabildiği gerçeğinden hareket edilmektedir. Böylelikle farklı profildeki kişilerin farklı deneyimleriyle mekândaki değişimi farkı biçimlerde algıladıkları da bu yöntemin kent sakinlerine odaklanması sayesinde ortaya çıkabilmektedir.

Miaux, ${ }^{23}$ son yıllarda mekânla ilgili çalışmalarda niteliksel araştırmaların çok daha fazla kullanılmaya başlandığını, çünkü bu tür araştırmalarda yaşanan mekânla ilgili algılara ve öznel yorumlara çok daha fazla yer verilebildiğini belirtmektedir. Bu bağlamda Miaux (2010), kentte yaya olma deneyimini araştırmış, bu araştırmayı "mekânla ilişki halindeki hareketli beden" kavramsallaştırması üzerinden yapmıştr. "Seyahatname" ${ }^{24}$ olarak adlandırdığı yöntemi, kent içinde yürüyen bir yolcuyla birlikte yürüyüp sohbet ederek ve o süreçteki deneyimi not ederek uygulamıştır. Yürüyüş sırasında rotanın nerelerden geçtiğinin yanı sıra yürüyüş sırasında karşılaşılan mekânlar ve bedensel deneyim de seyahatnameye eklenmiştir.

Gezici yöntemler içinde "birlikte gitmenin (go-along)" önemli bir niteliksel araştırma aracı olduğu vurgulanır. ${ }^{25}$ Hollywood'daki komşuluk ünitelerinde gerçekleştirdiği araştirmasında Kusenbach, 60 kadar kişiyle gün boyu birlikte gezerek araştırmasını yapmıştır. Yazar, bu yöntem sayesinde 5 ana meseleye kolaylıkla odaklanabildiğini belirtir: 1) çevresel algı, 2) mekânsal pratikler, 3) yaşam öyküleri, 4) toplumsal mimarî ve 5) toplumsal hayat. Yazar (Kusenbach, 2003: 464), araştırmasında bu bağlamda kullandığı ve birlikte gitme olarak adlandırdığı yöntemi 5 farklı mahallede yaşayanların sorunları nasıl algıladıkları$\mathrm{nı}$, nasıl ifade ettikleri ve bu sorunlar ile yaşayanlar arası iletişimin birbiriyle nasıl etkileştiğini anlamaya çalışmıştr. Araştırmacı ile araştırma katılımcısının birlikte hareket ettiği bu yöntemi Kusenbach, hem arabayla hem de yürüyerek gerçekleştirmiş, araştırma katılımcısı ile birlikte zaman geçirirken bir yandan notlar alıp, diğer yandan fotoğraf çektiğini belirtmiştir. Kusenbach'a göre, birlikte yürümek, daha yavaş ilerleyebilmenin mümkün olması ve çevrenin daha kolay algılanabilmesi açısından araçta olmaktan çok daha etkindir. Katılımcı ile araştırmacının birlikte hareket ettiği bu teknikte Kusenbach bu hareketin bağlamının da tamamen araştırma katılımcısının gündelik hayatının bir kesitini ortaya koyar nitelikte olması gerektiğini vurgulamakta ve yöntemi "doğal birlikte gitme" olarak da adlandırmaktadır.

Yürü ve konuş metodunun son yıllarda daha da yaygın olarak kullanıldığını belirtenler, bu yöntemle mekânla insan ilişkisinin çok daha iyi kurulabildiğini, araştırmaya katilanların ne söylediklerinin yanı sıra, bunu nerede söy-

\footnotetext{
${ }^{23}$ Miaux, vd. 2010: $1166 . \quad{ }^{24}$ Itinerary. $\quad{ }^{25}$ Kusenbach, 2003
} 
Tablo 1. Hareketli Yöntemlerin Temel Farklııkları (Makale kapsamında hazırlanmıştır)

\begin{tabular}{|c|c|c|c|c|}
\hline & $\begin{array}{l}\text { Kusenbach } 2003 \\
\text { (go-along) }\end{array}$ & $\begin{array}{c}\text { Anderson } 2004 \\
\text { (Talking whilst walking) }\end{array}$ & $\begin{array}{c}\text { Layeb } 2014 \\
\text { (segmented walk) }\end{array}$ & $\begin{array}{c}\text { Patiteau } 2006 \\
\text { (Methodes des itineraire) }\end{array}$ \\
\hline $\begin{array}{l}\text { Araştırmacı mekanı } \\
\text { tanıyor mu }\end{array}$ & Hayır & Hayır & $\begin{array}{l}\text { Evet (önceden mekân } \\
\text { hakkında bilgi toplar) }\end{array}$ & $\begin{array}{l}\text { Hayır (tanıyıp tanımaması } \\
\text { yöntem için bir kriter değil) }\end{array}$ \\
\hline Katılımcı mekanı tanıyor mu & Evet & Evet (tanıması bir şart değil) & Evet & Evet \\
\hline Rota kim tarafından çiziliyor & Katılımcı & Katılımcı & Katılımcı & Katılımcı \\
\hline Araştırma süresi ne kadar & $\begin{array}{l}\text { Bütün gün } \\
\text { görüşmeceyle geçirilir }\end{array}$ & $\begin{array}{c}\text { Bir görüşme bitene kadar } \\
\text { yaklaşık 1-2 saat }\end{array}$ & $\begin{array}{l}\text { Bir görüşme bitene } \\
\text { kadar yaklaşık 1-2 saat }\end{array}$ & $\begin{array}{c}\text { Bir görüşme bitene kadar } \\
\text { yaklaşık 1-2 saat }\end{array}$ \\
\hline Veriyi haritalıyor mu & Hayır & Hayır & Çoğunlukla Evet & Kesinlikle Evet \\
\hline Araştırmacının rolü & $\begin{array}{l}\text { Bir gölge gibi } \\
\text { katılımcının gündelik } \\
\text { rutinlerini inceler }\end{array}$ & $\begin{array}{l}\text { Bilgi toplama amacıyla } \\
\text { sohbet eder }\end{array}$ & $\begin{array}{l}\text { Belirlenen ve daha } \\
\text { önceden araştırdığı } \\
\text { konuyla ilgili daha } \\
\text { derinlemesine bilgi } \\
\text { toplamaya çalışır }\end{array}$ & $\begin{array}{l}\text { Belirlenen ve daha } \\
\text { önceden araştırdığı } \\
\text { konuyla ilgili daha } \\
\text { derinlemesine bilgi } \\
\text { toplamaya çalışır }\end{array}$ \\
\hline
\end{tabular}

lediklerinin de çok önemli olmaya başladığını vurgulamaktadır. ${ }^{26}$ Kusenbach'ın ${ }^{27}$ yöntemini "gölge yöntemi" olarak adlandıran Jones ve diğerleri, gölge gibi saatlerce veya günlerce katılımcıyı takip etmenin onunla daha derinlemesine bir ilişki kurulmasını sağladığını belirtmiştir. Birlikte gitme yöntemini kullanan diğer bir araştırmacı Carpiano ise, yöntemin kurgusunun farklı şekillerde yapılabileceğini belirtmektedir. Carpiano'ya göre, ${ }^{28}$ yapılandırılmıs sorular aracılığıyla ya da yarı yapılandırılmıs olarak yalnızca belirli temalarla da bu yöntem başarıyla gerçekleştirilebilir. Yöntemi mahalle sağlığı ile ilgili araştırmasında kullanan Carpiano, hem saha gözlemini hem de yüz yüze görüşmeyi içinde barındırdığı için katılımcıyla birlikte dolaşmanın çok avantajlı olduğunu belirtmektedir. Ayrıca Carpiano bu yöntemin yalnızca sorun tespiti ve çözüm arayışında etkin olması değil, sonrasında da toplumda bir güçlenme ve farkındalık yaratabileceğini, bu sebeple de toplum tabanlı katılımcı araştrmalarda kullanılabilecek önemli bir teknik olduğunu ortaya koymaktadır.

Bunlarla benzer olarak Ross, ${ }^{29} 8$ gencin gündelik hayatna dair yaptıkları bir araştırma ile karşımıza çıkar. Gençlerle gündelik yaşamlarında birlikte tura çıkarak araştırmalarını yapan yazarlar ${ }^{30}$ bu yöntem sayesinde yalnızca anlatılan bilgilere değil, bedensel ve duygusal hareketleri, hissedilenleri, koklananları, görülenleri de kaydetmenin mümkün olduğunu belirtmektedirler.

Anderson $^{31}$ ise, mekânın ve kimliğin birbirini oluşturduğu iddiasıyla yola çıkarak ampirik örnekler ve belgeseller aracılığıyla yerinde sohbet etmenin ve birlikte yürüyerek araştırma yapmanın önemine dikkat çekmektedir.

\footnotetext{
${ }^{26}$ Jones, Bunce, James, Gibbs ve Ricketts, 2008.

27 Kusenbach, 2003.

${ }^{28}$ Carpiano, 2009: 265
}

Anderson gibi mekân ve insan belleğinin birbiriyle bağını vurgulayan Petiteau ile Pasquier ${ }^{32}$ ise rehberli gezi yöntemini tartş̧maya açarlar. Bu yöntem, tarihsel bir perspektifi de işin içine katarak, coğrafi bir düzlemde inceleme yapabilmeyi mümkün kılması açısından diğer yöntemlerden ayrılabilmektedir. Yazarlar, bir soruna odaklanmış olma zorunluluğu olmadan, hikâyeleri toplayan yöntemle, bu hikâyelerin mekânlarla karşılaşmalarla istemsiz belleği harekete geçirebildiklerini belirtirler. Bu yöntem, istemli ve istemsiz bellek arasındaki ilişkiye ve kentsel mekânın deneyimlenmesinin yanı sıra pek çok duygu, algı ve tarihsel birikimin bir araya getirilmesine odaklanır. Petiteau, ${ }^{33}$ rehberli gezi yönteminin sosyal bilimler arasındaki ayrıma odaklanmadığını, belirli bir süre içerisinde ve belirli bir rota boyunca anlatılan hikâyeyi temel aldığını, bu süreçte anıların bugünle buluşarak karşımıza yeniden geldiğini belirtir. Bundan etkilenerek kentteki sesleri takip eden Layeb, ${ }^{34}$ Tunus'ta bir yaya yürüyüş parkurunda yapttğı rehberli gezilerle seslerin ve formların algısını anlamaya çalışmıştır.

Bu yöntemle, bir yol boyunca, farklı mekânlar, bu mekânlar hakkındaki deneyimler ve bedenler arası bir alışveriş yaşanması beklenir. ${ }^{35}$ Özellikle Proust'un iki farklı bellek tarifinin de bu yöntemde yerini aldığını söyleyebiliriz: İstemli bellek ve istem dışı bellek. Bu yaklaşım Deleuze'ün Proust ile ilgili yazdığı kitabından çokça etkilenmiştir. ${ }^{36}$

Tablo 1, hareketli araştırma yöntemlerinin temel farklılaşma eksenlerini ortaya koymaktadır.

\section{Selçuk ve İznik'in Morfolojik Dönüşümü}

Araştırmalarda, kentlerin nasıl dönüştükleri saptanırken

\footnotetext{
32 Petiteau, 2006a; Petiteau ve Pasqu- ${ }^{34}$ Layeb, 2014.

ier, 2001.

${ }^{33}$ Petiteau, $2006 b$.
} 
rehberli gezi öncesinde kartografik yeniden çizim yöntemi kullanılarak kentlerin morfolojik dönüşümü harita üzerinden saptanabilmiştir. Bu hava fotoğrafları üzerinden yapılan çalışma, kentlere dair bize temelde çok önemli birkaç bulguyu sağlamıştır. Bunlardan biri kent sınırlarının nasıl değiştiğinin saptanmasıdır.

Selçuk kentinin hava fotoğrafları üzerinden kartografik yeniden çizim yöntemi kullanılarak inceleme yapıldığında 1950'lerde kentin doğu - batı yönünde geliştiği görülür (Şekil 1).

Elimizde bulunan 1977 yılı fotoğrafinda ise kuzey ve güneye doğru gelişmenin başlamış olduğu, ancak kentin tam güneyinde kalan meyve bahçelerinin hala varlığını koruduğu görülür. 1994 yılında İsa Bey mahallesinin gecekondu önleme bölgesi olarak ilan edilmesiyle birlikte ise kent için çarpıcı bir dönüşümün başladığı görülür. 2009 hava fotoğrafina bakıldığında ise, kent içindeki boşlukların yoğun bir biçimde bu dönemde dolduğu ortaya çıkar. Selçuk'un bu gelişimi haritalara ve toplanan verilere bakıldığında yasal

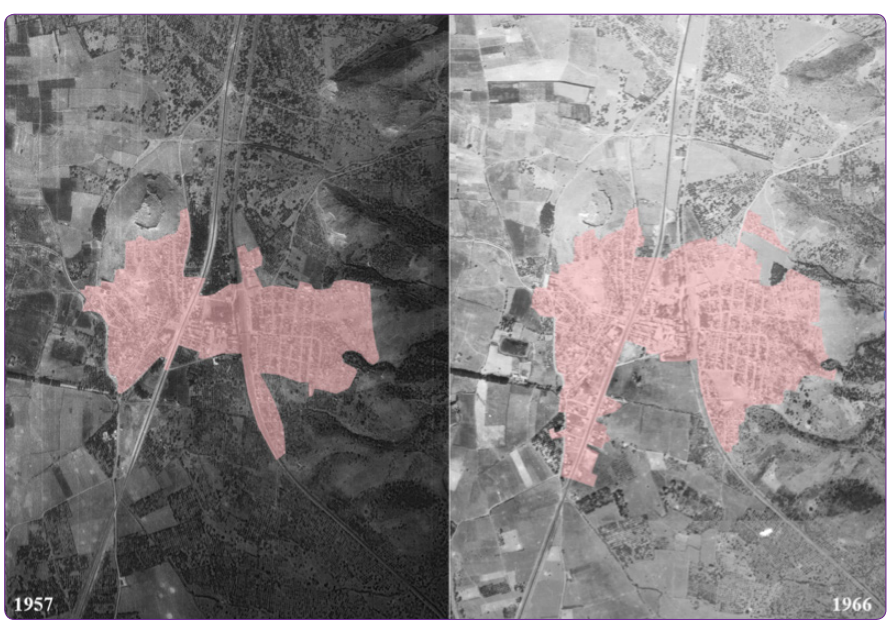

Şekil 1. Selçuk Kenti 1957 - 1966 Kartografik Yeniden Çizim Kent Sınırları (Yücel ve Aksümer, 2018).

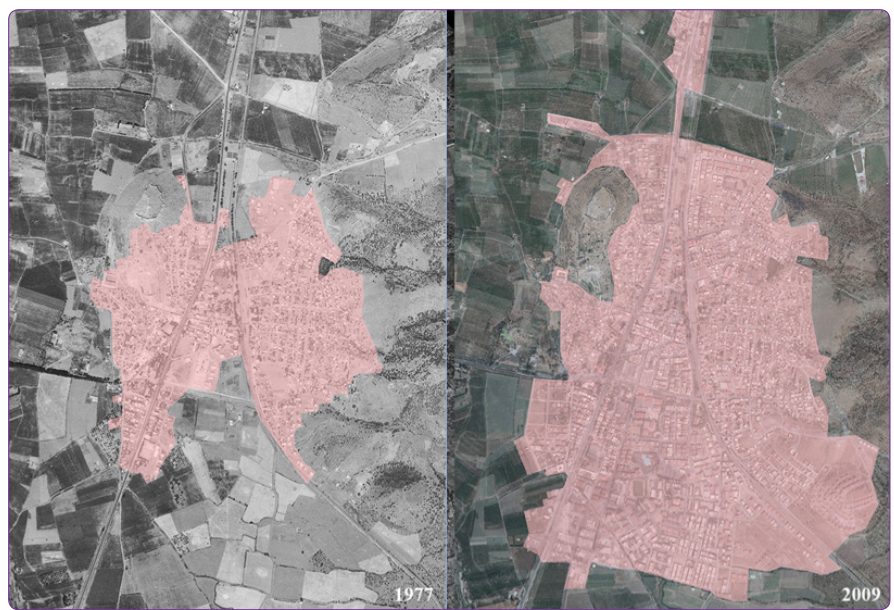

Şekil 2. Selçuk Kenti 1977 - 2009 Kartografik Yeniden Çizim Kent Sınırları (Yücel ve Aksümer, 2018). süreçlerle ilişkilendirilebilmiştir. Bu değişimlerin yaşayanlar tarafindan da çok net biçimde algılandığı, bütün yasal süreçlerin de kent sakinleri tarafindan dile getirildiği ve kentin gelişim yönlerinin doğru analiz edildiği rehberli gezi yöntemi ile görülür. İznik kentinde ise sınırlayıcının sur olduğu çok daha belirgin bir morfolojik değişim olduğu görülür. Sur içi ve sur dışının farklı biçimlerde geliştiği ve yerleşimin sur dışında çıktıktan hemen sonra çok yoğun bir şekilde devam ettiği anlaşılır (Şekil 2).

1943 - 1973 arasında yerleşik alanın sur içinde sınırlı kaldığı gözlenir. Bu süreçte sur sınırlayıcı bir etki yaratmakta, diğer yandan sur içindeki işlevler ve planlı kent dokusu da kentin burada gelişmesinin kolaylaştırıcıları olmaktadır (Şekil 3).

1973 yılından 1997 yılına gelindiğinde ise yerleşimin sıçramalı bir şekilde özellikle kuzeyde göl kıyısına doğru yayıldığı, güneyde surun hemen bitişinde ise dış yerleşimin başladığı görülmüştür. 1997 yılında bu yayılma görülmüş olsa da 2011 yıll, kentsel büyümenin çarpıcı bir biçimde karşımıza çıktığı bir görüntüyü karşımıza çıkarır. 1997 yılında Sıçramalı şekilde gelişen kent parçaları artık sur içiyle birleşmiş, yerleşik alan yağ lekesine benzer bir biçimde gelişmiştir. Bu fotoğraflardan bakıldığında kentin 2011 yılında kadar çokça büyüdüğü görülmekte ve dolayısıyla hem sektörler hem de kentsel yaşam anlamında gelişme göstermiş olabileceği çıkarsaması yapılabilir (Şekil 4).

İkinci bulgu ise, kentlerdeki büyük fonksiyonların nasıl değiştiğinin hava fotoğraflarından saptanması olmuştur. Örneğin Selçuk'ta meyve bahçelerinin uzun yıllar

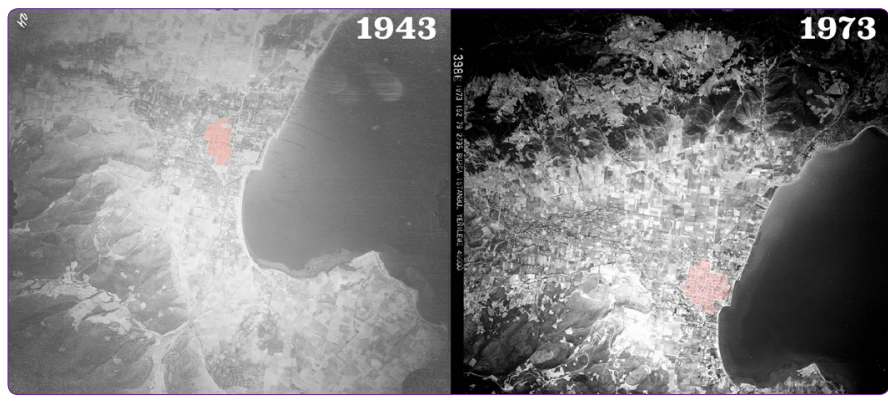

Şekil 3. İznik Kenti 1943 - 1973 Kartografik Yeniden Çizim Kent Sınırları (Yücel ve Aksümer, 2018).

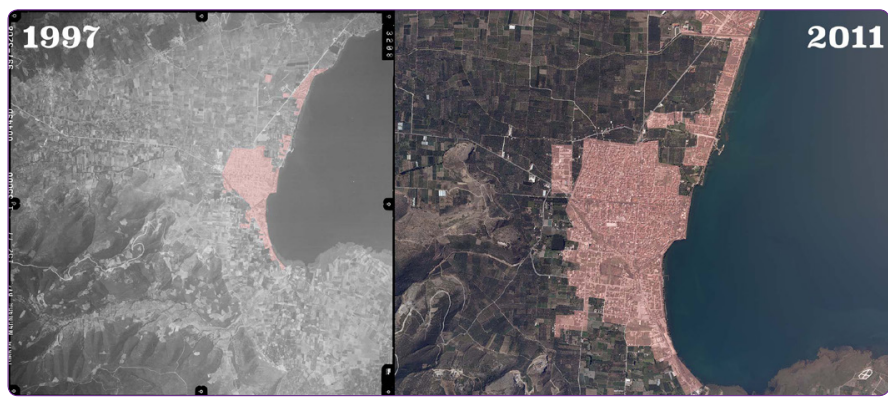

Şekil 4. İznik Kenti 1943 - 1973 Kartografik Yeniden Çizim Kent Sınırları (Yücel ve Aksümer, 2018). 


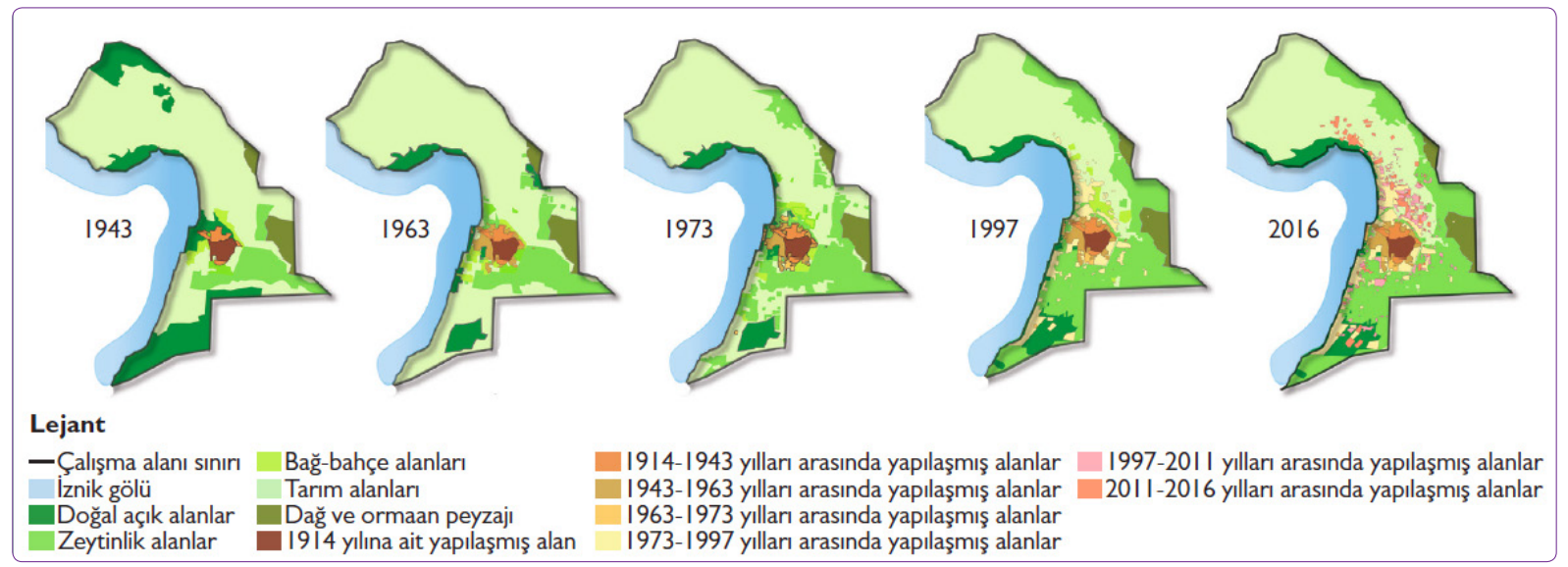

Şekil 5. ̇̇znik Kenti 1943 - 2016 Fonksiyonların Değişimi (Salt, 2017).

yapılaşmadığı, ancak 1977 sonrasında bu bölgelerin yapılaşmaya açıldığı görülür ve bunu hava fotoğrafları ile saptamanın mümkün olmuştur. İznik'te ise özellikle göl kenarında kuzey - güney doğrultusunda sitelerin yer almaya başladığı yine hava fotoğraflarının analiziyle ortaya çıkar (Şekil 5).

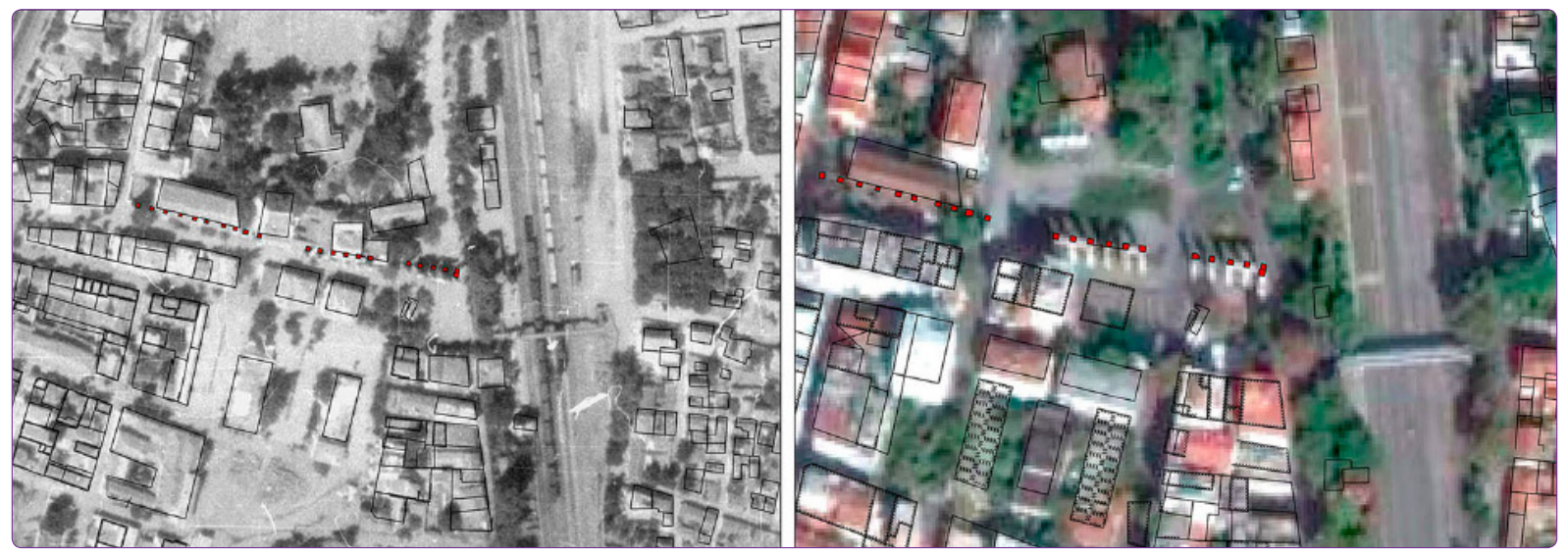

Şekil 6. Selçuk Kenti Dokunun Değişimi (Yücel ve Aksümer, 2018).

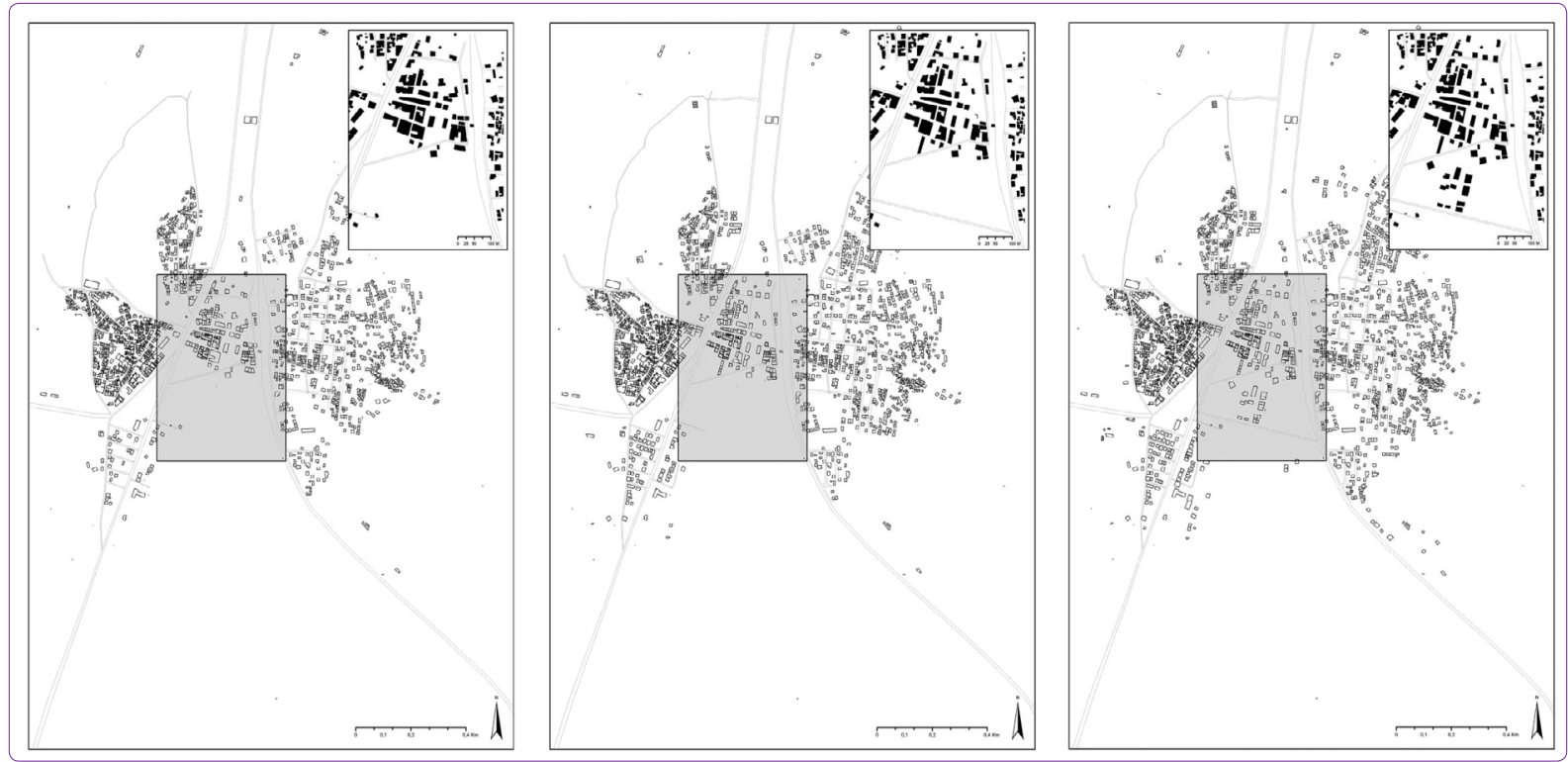

Şekil 7. Selçuk Kenti Su Kemerlerindeki Değişim (Yücel ve Aksümer, 2018). 
Üçüncü bulgu ise kent dokusunun nasıl dönüştüğünün saptanması olmuştur. Örneğin Selçuk kentinde merkezi ve kentin güneyini içine alan bölgedeki dokunun neredeyse hiç değişmediği, buna karşın 1977'deki haritalarda kent dokusunun güneye doğru aktı̆̆ı olduğu açıkça görülür (Şekil 6).

Hava fotoğraflarına yakınlaşarak baktığımızda ise hangi binaların nasıl değiştiğini, hangi dokunun eskiden var olup şimdi ortadan kalktığını görmek mümkün olabilmiştir (Şekil 7).

\section{Rehberli Geziye Başlarken: Araştırmaların Kurgusu ve Karşımıza Çıkan Temalar}

Araştırmaların temel amacı, kentlerin, özellikle kent makroformlarının yıllar içinde nasıl değiştiğini saptamaktır. Bu bağlamda öncelikle kartografik yeniden çizim yöntemi sayesinde kentlerin hangi yönlere nasıl bir gelişme sağladığı anlaşılmış, ardından kentlerin farklı bölgelerini kapsayan, kentlilerle yapılan gezilerle kentlilerin bu değişimle ilgili algısı ve yorumları toplanmıştır. Bu noktada rehberli gezinin niceliksel araştırmanın destekleyicisi olarak kullanıldığı Selçuk araştırması ile nicel ve nitel araştırmanın aynı ağırlıkta kullanıldığı İznik araştırması sonuç ürünlerindeki ayrıntılar bakımından birbirinden farklılaşmıştır.

Araştırmalarda, farklı sosyo-ekonomik aidiyetleri olan ve kentin farklı bölümlerinde yaşayan kadınlar ve erkeklerle (araştirma boyunca 'rehber' veya katlımcı olarak adlandıracağız. Araştırmaya katılanların hepsi rehberli gezi sürecinde de yer almışlardır.)

Özellikle rehberli gezi yönteminin özelliği sebebiyle katilımcılara bir soru föyü hazırlanarak gidilmemiştir. Yalnızca kentin değişim ve dönüşümüne dair bildiklerini anlatmaları istenmiştir. Böylelikle hem rehberin anlattkları tüm detaylarıyla kayıt altına alınırken, hangi konunun neyle ilişkisi olduğu ve bunun harita düzlemindeki görünümü işlenebilmektedir.

íki sahanın da başlangıç öyküsü ve katılımcılarla kurulan ilişkiler benzer olsa da, birbirinden ayrıldıkları noktalar bulunmaktadır. İki araştırmada da kentteki kamu kurumları ve muhtarlıklarla görüşülerek, öncelikli olarak uzun yıllardır bu kentte yaşayan kişilere ulaşılmaya çalışımıştı. Selçuk'ta belediyenin Kültür Müdürlüğüne bağlı "Kent Belleği” çalışma birimi araştrmanın bel kemiğini oluşturmuştur. Rehberlerin kentte en az 20 yıldır yaşamakta olması, birbirine yakın sayıda erkek ve kadın katilımcıdan oluşmaları araştırmanın belirleyicilerini oluşturmuştur. İznik'te ise belediye meclis üyelerinden destek alınabilmiştir. Farklı siyasal görüşlere sahip, farklı yaşam biçimleri olan ve çoğunlukla farklı mahallelerde yaşamakta olan meclis üyeleri ve onların arkadaşları ile görüşebilmek araştırmayı genişletmekte yardımcı olmuştur.

İki araştırmada da yapılan görüşmeler döküldüğünde ve en çok tekrar edilen konular, kelimeler anlamlı bir şekilde kategorize edildiğinde ortak temalar karşımıza çıkmaktadır.

\section{SINIR}

KENT BELLEĞi BINASI GECEKONDU ÖNLEME

EFES AÇIK HAVA SINEMASI

CARPUZA

EVLER tREN ISTASYONU

MEYVE BAHCELERI

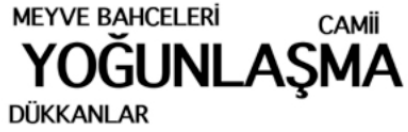

DUKKANLAR

Kelime Bulutu 1. Selçuk ve İznik Araştırmaları Kelime Bulutları.

Yukarıdaki kelime bulutlarından soldaki Selçuk, Sağdaki ise İznik kentlerinde yapılan rehberli gezilerde en çok konuşulan konuları göstermektedir. Bu anlamda iki araştırmada da en çok göze çarpan temalardan biri sınır öğesidir. Selçuk kentinde bu daha çok kenti sınırlandıran doğal alanlar ve sit alanlarından konuşurken ortaya çıkarken, İznik'te surlar ve göl üzerine yapılan konuşmalar bu anlamda hep sınır meselesinin konuşulduğu sohbetler olmuştur. íkinci olarak kamusal mekanların sıklıkla karşımıza çıktığı, bununla ilişkili noktalarda ise toplumsal özelliklere ilişkin dönüşümlerden bahsedildiği görülmüştür. Örneğin, kentin yoğunlaştı̆̆ından bahsedilirken Selçuk'ta komşuluğun eskisi gibi olmayışından bahsedilmiş, İznik'te ise göl kullanımının, Pazar yerlerinde karşılaşılan insanların artik daha muhafazakar oldukları vurgulanmıştır. Son olarak ise binalar, sokaklar, evler, dükkanlar gibi konularla çok küçük ölçekteki fonksiyon değişimlerinin vurgulandığı görülür.

\section{Kentin Sınırlarının Belleklerdeki Yeri}

Yapılan araştırmaların ikisinde de kentin sınırlarının nasıl değiştiği, rehberlerin hayatları boyunca en çok takip edebildikleri kentsel değişim katmanı olmuştur. Kentin nerede bitip nerede başladığını hikâyelerle anlatan rehberler, kimi zaman kanunlara, planlara da referans vermişlerdir. Bu anlamdaki ilk bulgu, rehberlerin, kentteki değişimleri 10'ar yıl gibi geniş periyodlarla ifade ettikleridir. Sınırlardaki değişim hızlı bile olsa çok kısa dönemlerde ortaya konamamaktadır. İkinci bulgu ise kartografik yeniden çizim yöntemi ile ortaya konan sınırlardaki değişim ile rehberlerin bahsettiği sınır değişimlerinin iki kentte de neredeyse üst üste oturduğudur. Dolayısıyla rehberler ile sınır boyunca yapılan gezinti, bu değişimin neredeyse gerçeğine yakın olarak haritalanmasını sağlayabilmektedir.

Selçuk kentiyle ilgili rehberlerin en çok vurguladıkları morfolojik değişim 1950'lerden sonra kentin hızlı bir yapılaşma sürecine girdiği olmuştur. Bu gelişmeyle Selçuk, oldukça kompakt, etrafinda Efes antik kenti ile önemli bir çevre yolunun bulunduğu bir kent olarak sınırlandırılmıştır. Bu bağlamda sınırların nerede bitip başladığı, hangi yıllar- 
da nasıl değişimler gösterdiği rehberler tarafindan açıkça ifade edilebilmiştir (Şekil 8).

İznik kentinde de surların özellikle sur içi ve sur dışı olarak kenti iki katmana ayırdığının rehberler tarafindan ifade edildiği, üstelik bu ayrımın yerleşme açısından da tarihsel bir izdüşümü bulunduğu görülmüştür (Şekil 9).

Diğer yandan doğal alanların rehberlerin belleğinde sınır oluşturdukları görülmüştür. İznik gölü de bir sınır oluşturmakta, gölün büyüklüğündeki değişim de rehberler tarafindan anlatılarak bu sınırın nasıl değiştiği ortaya konmaktadır.

Selçuk'ta ise bu sınır daha çok meyve bahçelerinden oluşmuş ve bu bahçelerin yapılaşmasıyla dönüşmüştür. Görüşmecilerden Emrullah Kutlu: "Bademlik'te incir ve zeytin ağaçları vardı. Eski adı Bademlik, şimdi Zafer Mahallesi'dir adı." şeklinde belirtmekte ve bunu söylerken hem oranın doğal yapısının dönüşümünü hem de isminin dönüşümünü aynı anda dile getirmektedir.

\section{Toplumsal İlişkilerdeki Dönüşümün Mekandaki İzleri}

Mekansal ve toplumsal ilişkilere dair ilk sonuç, rehberli

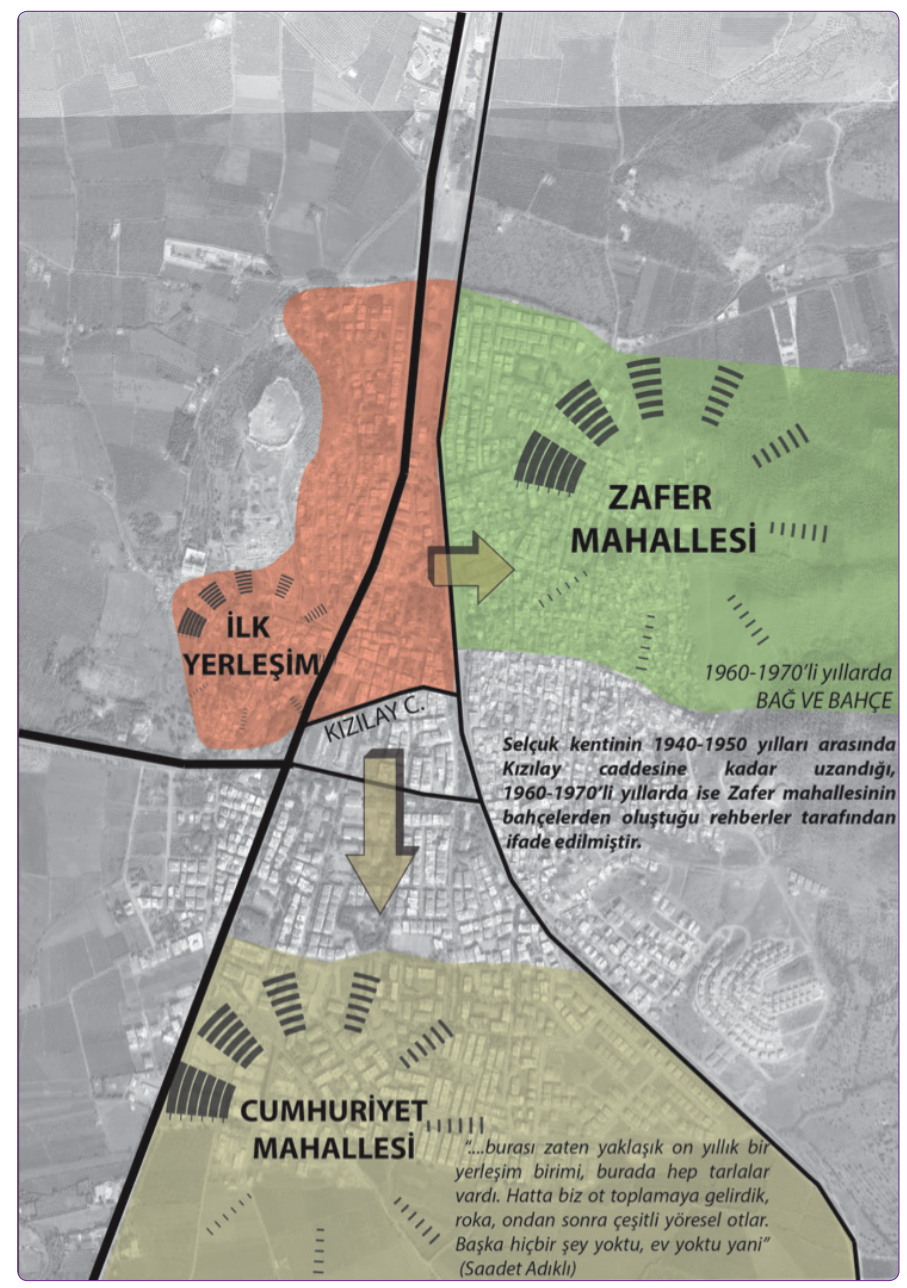

Şekil 8. Selçuk'un gelişimi. gezi sayesinde, toplumsal değişimin yalnızca sözel olarak değil mekânlarla bağlantılı olarak karşımıza çıkmış olmasıdır. İki kent için de toplumsal değişim rehberler tarafindan kamusal mekanlara, boş zaman aktivitelerinin geçirildiği mekanlara ya da sokaklara referansla anlatılmıştır.

Selçuk kentinde Efes antik kentinin kullanımı ile ilişkilenen bir anlat karşımıza çıkarken, İznik kentinde ise göl en önemli referans noktası olmuştur. İki kentte de toplumsal ilişkilerin nispeten zayıfladığına dairdir. Nispeten küçük kentler olmalarına rağmen eskiye göre komşuluk ilişkilerinin zayıf olması, sokakta karşılaşanların birbirlerini artık tanımıyor olmaları da iki kentteki ortak sonuçlardır. Üçüncü olarak kentte festivaller gibi birlikte yapılan aktivitelerin azalmasının da bir arada olma duygusunu zayıflattğı rehberli geziler sayesinde ortaya çıkmıştr. Dördüncü bulgu ise, dışarıdan gelen insanlarla ilişkinin kent yaşamını nasıl etkilediği hakkında olmuştur. Bu anlamda Iznik'te ikinci konut sahipleri ve TOKi konutlarında yaşayanlarla ilişkilen çok zayıf olduğu görülür.

Selçuk kentinde ise ikinci konut ya da TOKi gibi kent dışında bir yerleşim olmadığı, 'dışarıdan' olarak adlandıracağımı kişilerin ise yalnızca turistlerden oluştuğu görülür.

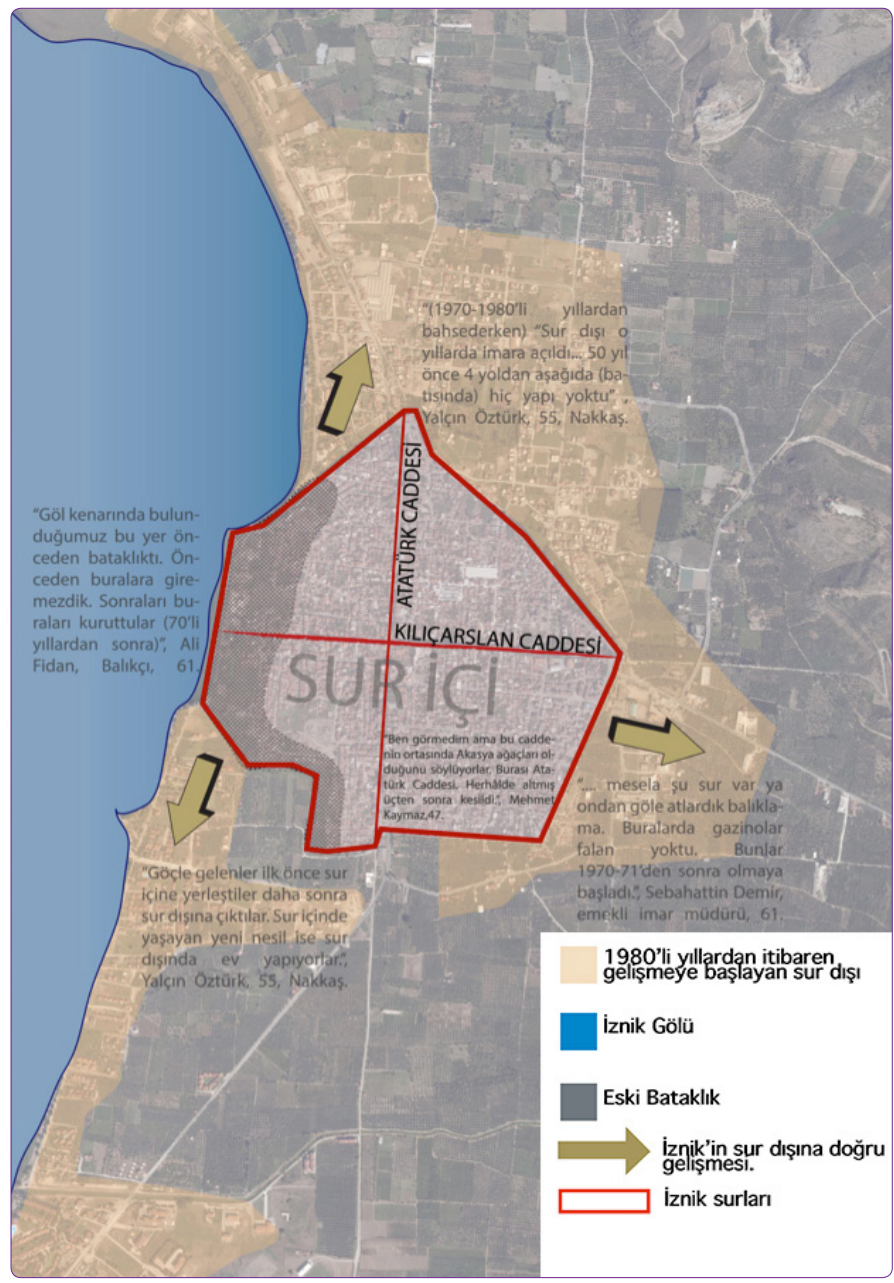

Şekil 9. ̇̇znik'in gelişimi. 


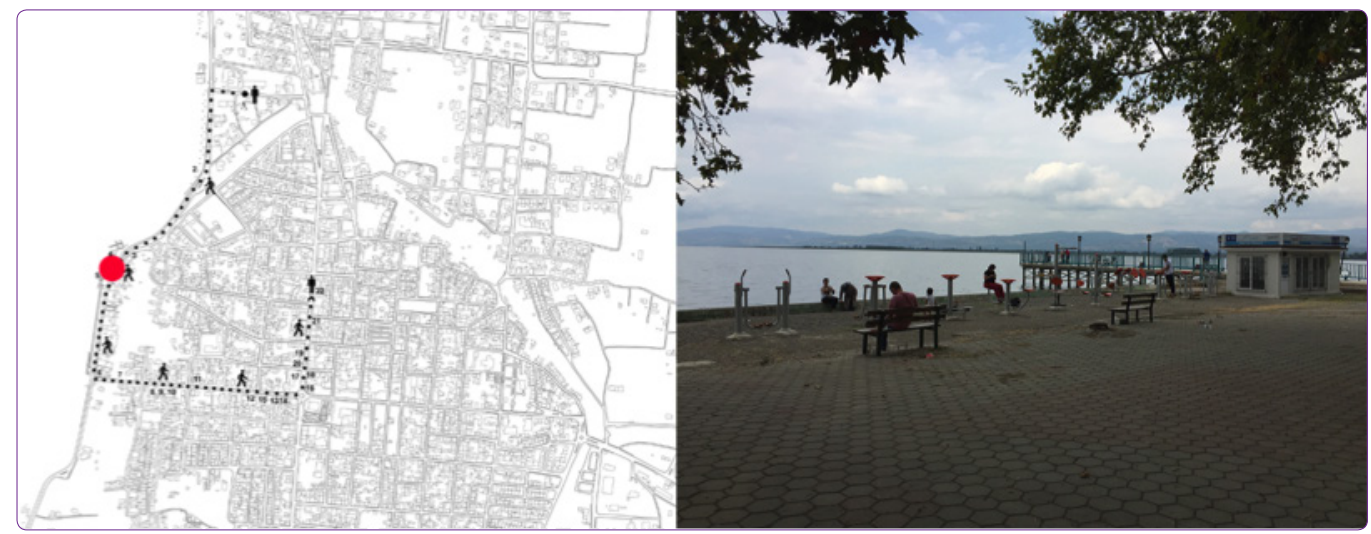

Şekil 10. İznik göl kenarı - Resmiye Hanım’ın rotası.

Turistlerle ilişki ise Selçuk kentinde daha çok dışa açılmayı getirdiği rehberler tarafindan dile getirilmiştir. Bugün turistik mekânların kaybedilmesinin, özellikle Efes'in Selçuk kentinden tamamen ayrılarak daha korumacı bir yaklaşımla kapatılmasının kenti toplumsal anlamda olumsuz etkilediği, turist akışını azalttğı ve özellikle Selçuk'un dışa daha kapalı bir kente doğru gittiği anlaşılmıştr.

Salih Bey ise, Selçuk'taki turizmin dönüşümünü anlatırken aynı zamanda bu durumun uluslararası olaylarla nasıl bağlandığını anlatır:

“Eskiden 1993'ten evvel Selçuk'a çok daha fazla kalıcı turist geliyordu neden Yugoslavya yolu açıkt... 1989 yılında bir patlama (turizm sektörünü kastederek) oldu. 200 tane pansiyon açıldı Selçuk'a. Yer bulunamadı. Turistler yerlerde uyukladı. O zamanlar turizmi tanıtma derneği başkanıydım. Ama 2-3 sene sonra pansiyonların hepsi kapanmaya başladı harp çok etkiledi turist gelmemeye başladı."

En güçlü bulgu olarak ise iki kentte de muhafazakârlaşma sürecinin yaşandığına dair ipuçlarından bahsedilmiş olsa da çok sayıda ve farklı kuşaklardan rehberlerle gerçekleştirilen İznik araştırmasında gündelik hayatın dönüşümüne ve bu dönüşümün mekândaki görünümüne dair Selçuk'a göre çok daha çeşitli ve somut örnekler ortaya koyulabilmiştir.

Iznik'te ise muhafazakârlaşma anlatısı çok daha ayrıntılı işlenmiştir. Bu muhafazakarlaşma, üç farklı mekânsal düzlem üzerinden somutlaştırılmıştır. Bu mekânlardan biri göl kenarı, diğeri çarşı ve sonuncusu ise kültür sanat ve eğlence mekanları olarak toparlayabileceğimiz panayır ve festival alanları ile kapanan sinemalar olmuştur.

Iznik'ten Resmiye Hanım kent içindeki gündelik hayaton ve özellikle de toplumsal ilişkilerin nasıl olduğuna dair ayrıntiları ortaya koyar. İznik'ten Resmiye Hanım kentin muhafazakarlık ekseninde farklılaştğını yine rehberli gezi sırasında karşılaştığı kişiler üzerinden anlatmıştır (Şekil 10):

"Işste iznik'in insanı böyle. Herkesle anlaşamıyorsun. Onlar daha mutaassıplar, biz mesela erkek ve kadın ayırt etmiyoruz, sohbet edebiliyoruz. Ama onlar hemen ayıplıyorlar. Ben o yüzden çok adapte olamadım."

\section{Kamusal Mekanların Bellekte Kalıcılığı}

Rehberli gezi, özellikle kamusal mekanların dönüşümünün ayrıntlı incelenmesi konusunda faydalı olmuştur. Anılar, rehberlere bir mekânın zamanın belli bir noktasında nasıl olduğunu ayrıntılı olarak anlatabilmeyi, o dönemdeki mekânsal durumu sözle ifade edebilmeyi, sınırları net biçimde ortaya koyabilmeyi mümkün kılar. Bu araştırmadan anlaşılan temel sonuçlardan biri, kamusal mekanların bellekte kalıcı bir yer tuttuğu ve bu yer sayesinde geçmişten bugüne ayrıntılı biçimde hatırlanabildiğidir. Burada özellikle kamusal mekânlar ile kentlilerin hayatında önemli bir yer teşkil eden tekil binaların farklı rehberler tarafindan anlatıldığı görülür.

Selçuk'tan Ayşe Hanım kendi gençlik anılarından bahsederken aslında bugün Carpuza kafe olarak bilinen bir mekânın nasıl dönüştüğünü anlatiyor (Şekil 11):

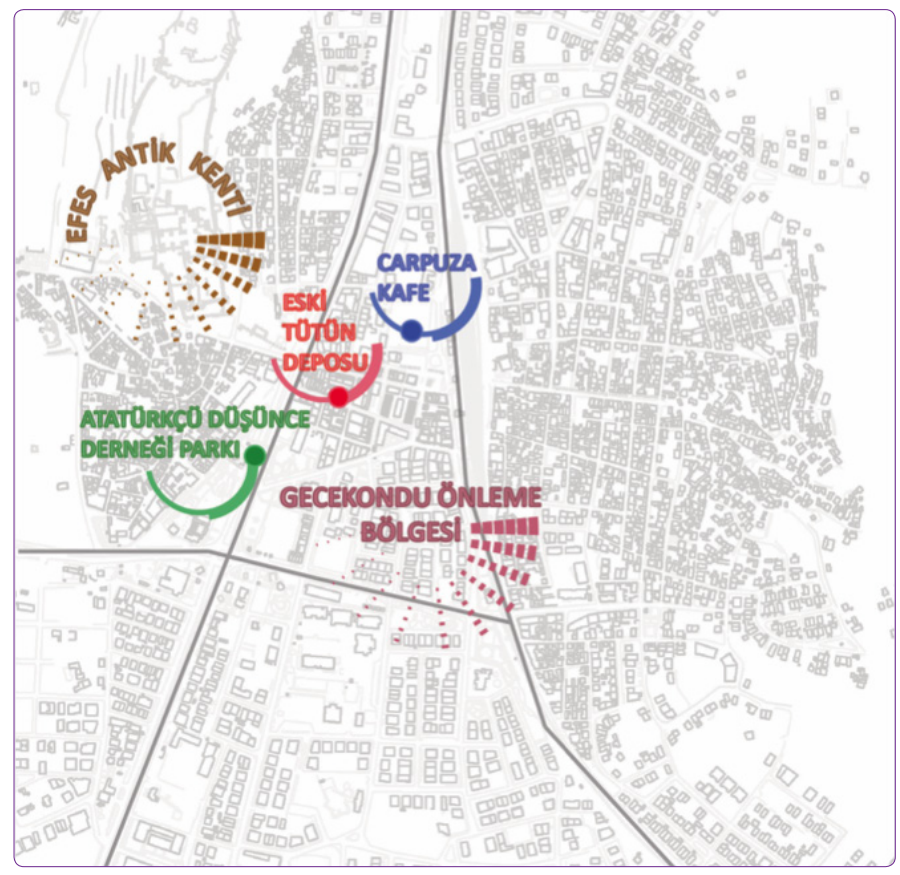

Şekil 11. Selçuk'ta en çok bahsedilen ortak mekânlar ve aktivite alanları. 
"Burası lojmandı ben beş buçuk yıl burada oturdum. Evliydim. Büyük oğlumu bu lojmanda doğurdum. Ve hayatımın en güzel beş yılını ben burada yaşadım. Her zaman bana hoş gelmiştir, küçücük bir evim vardı, küçücük bir mutfağım vardı. Şu palmiye ağacı var ya o ağaç bizim bahçenin içindeydi."

İnik'te de kamusal mekân kullanımlarının nasıl değiştiği konusu önem kazanmıştir. Deniz bey, gölün nasıl değiştiğini anlatırken kendi anılarına geçmekte ve şunları aktarmaktadır (Şekil 12):

"Gölde eskiden de yüzülüyordu ama eskiden yüzme sporuna daha çok önem verilirdi. Optimis adında bir yelken kulübümüz vardı. Türkiye çapında bir kulüptü, 1970-1980 arası çalışt, sonra bitti. 70'li tarihlerde çok güzel bir plajımız vardı. Turistler de geliyordu."

İznik'te üzüm festivali, panayır gibi kamusal etkinlikler neredeyse bütün rehberler tarafindan dile getirilmiş, kendi gençliklerindeki mekânlar hakkında ayrıntılı bilgiler verilmiştir.

"Üzüm Festivali yapılırdı buralarda. Ben onu hatırlıyorum. Yoğunluk oluyordu burada. Herkes katllıyordu, müthiş bir katılım oluyordu.",

İnik'ten Ahmet Bey de anılarında en çok yer eden panayır ve lunapark alanlarının nerede olduğunu göstererek ayrıntılarıyla anlatmaktadır.

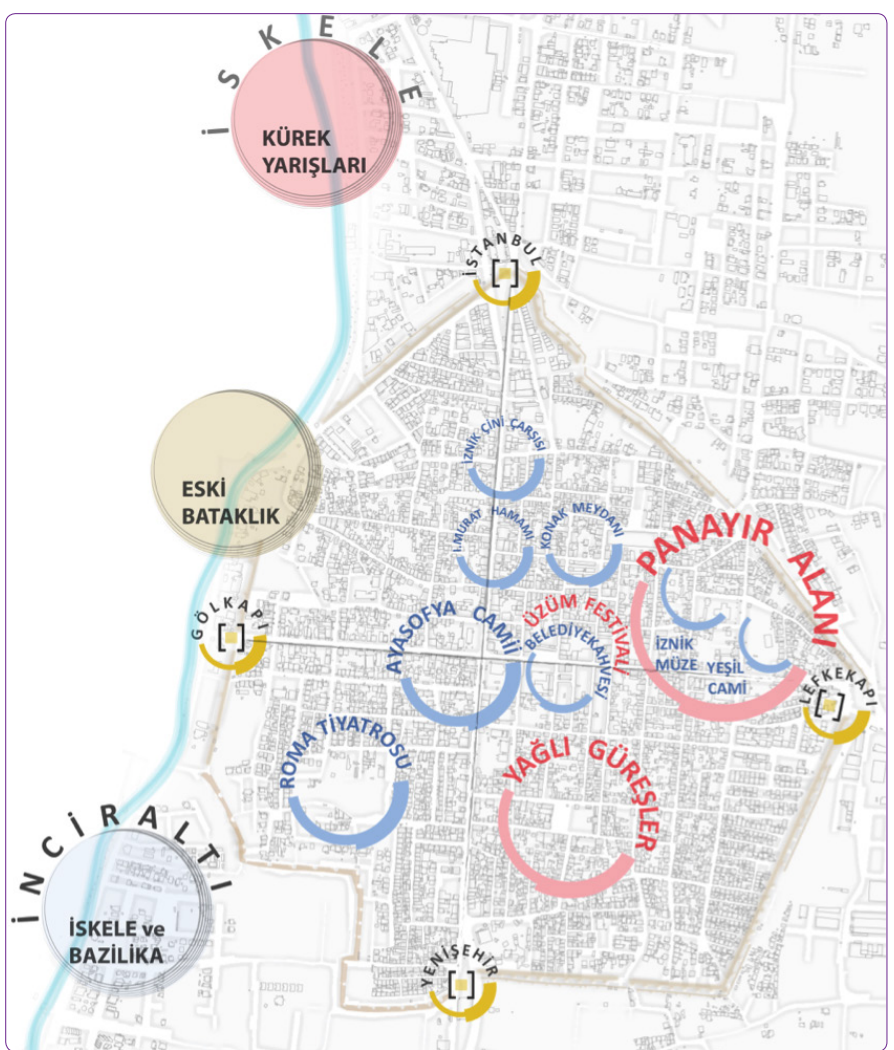

Şekil 12. İznik'te en çok bahsedilen ortak mekânlar ve aktivite alanları.

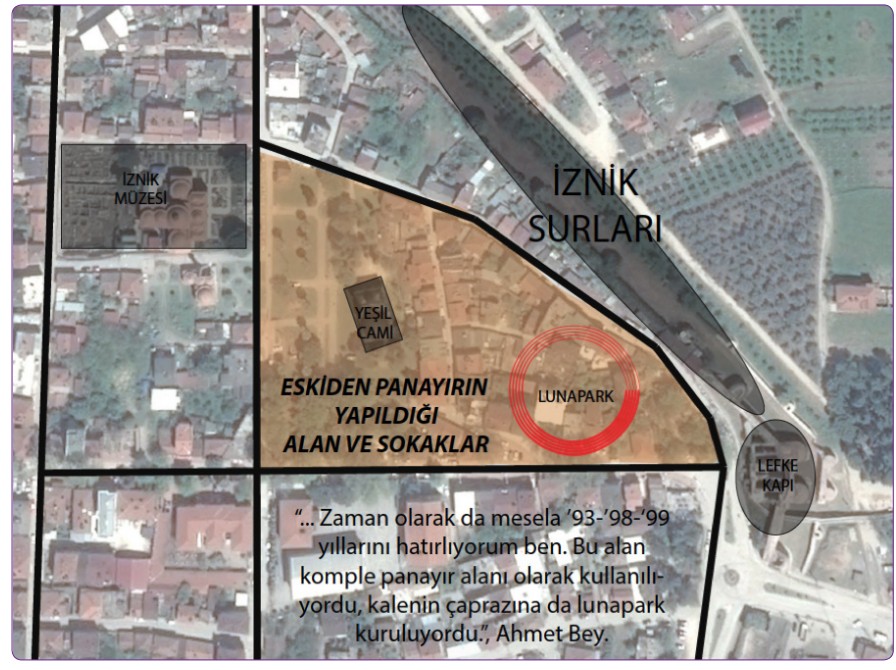

Şekil 13. İznik'teki Panayır Alanı Krokisi.

Mekânın krokisini çizmeye imkân vermesinin yanında rehberli gezi, o kroki içindeki fonksiyonel dönüşümleri de hızlıca belirleyebilmeyi kolaylaştırır (Şekil 13).

Kentin güney batısında yer alan park, bulunduğu kottan dolayı su baskınlarının yaşandığı bir alandır. Rehberler bu bölgenin tamamen sulak bir alan olduğu üzerinde durmaktadırlar. İsmail bey, bu bölgede kayıklarla gezdiklerini ve bunun o dönemki fiyatının 25 kuruş olduğunu hatırlayarak aktarıyor: "Eskiden burası olduğu gibi suymuş. Kayıklarla gezerdik 25 kuruşa".

Iznik'te ayrıca tarihi eserlerin hikâyeleri ve orada geçen anılar da rehberler tarafindan vurgulanan temalar olmuştur. Tarihi eserlerin kullanımındaki her değişim, kendi gündelik hayatlarını çokça etkilemiştir. Özellikle Ayasofya'nın camiye dönüşmesi ve ibadete açılması hem fonksiyonel bir dönüşümle hem de turistlerin azalmasıyla sonuçlanmıştir.

\section{Küçük Ölçekteki Dönüşümler}

Rehberli gezi, özellikle kartografik yeniden çizim yöntemi ile birlikte kullanıldığından dolayı, o yöntemin keşfedemediği küçük ölçekteki, hatta çoğu zaman parsel ya da bir yapı adası ölçeğindeki verileri ortaya çıkarmakta oldukça önemli bir rol üstlenmiștir. Selçuk'ta da, İznik'te de rehberler, kenti gezdirirlerken adım adım, sokak asfaltından, kaldırımlara, bina cephelerine ve binaların fonksiyonlarına kadar ayrıntılı bilgiler vermişlerdir. Bu dönüşümü tarihleriyle ve orada yaşadıkları anılar sayesinde çok kolay biçimde ayrıntılı olarak ortaya koymaktadırlar. Diğer yandan bu yöntem, bize kentlilerin çok küçük fonksiyon değişikliklerinden bile en az büyük sınır değişimleri kadar etkilendiğini göstermiştir.

Selçuk kentinde, rehberlerin en önemli vurgusu tek tek binalardan hangilerinin cephesinin, yüksekliğinin, boyutlarının nasıl değiştiği olmuştur. Özellikle belediye binası gibi kamusal binalar hakkında çokça yorum yapan rehberler, 


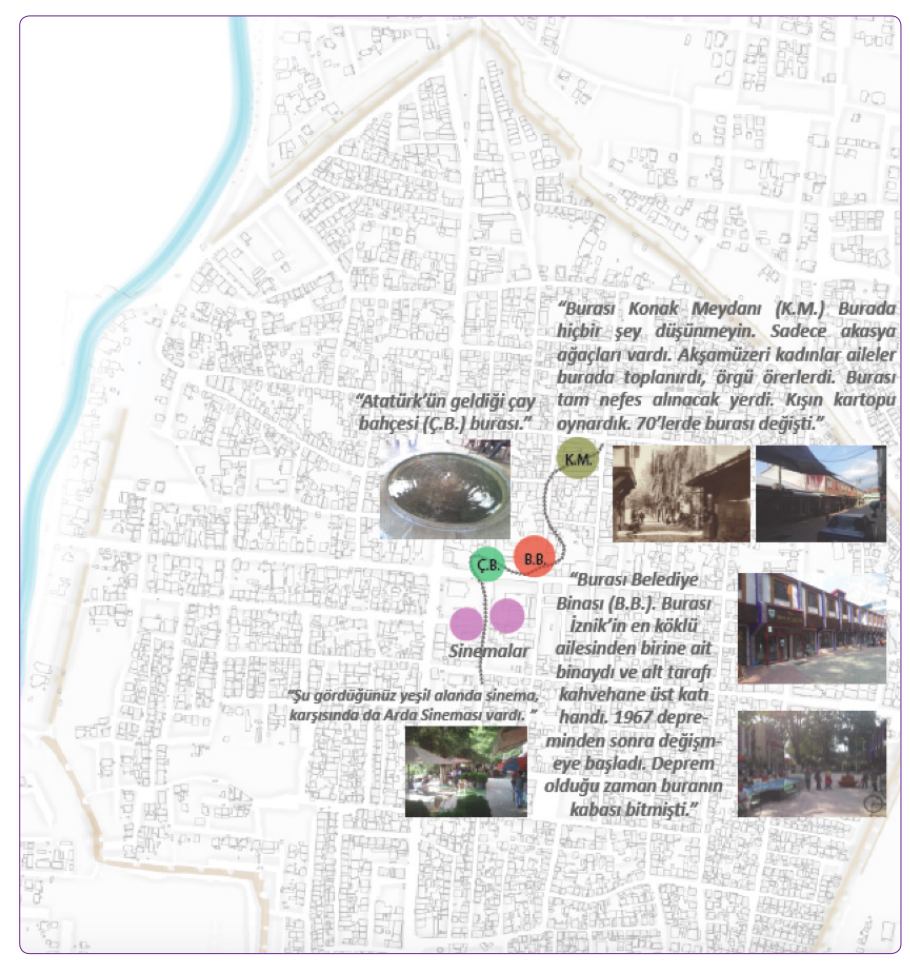

Şekil 14. İznik'te Merkez Krokisi.

hangi tarihte hangi binanın fonksiyonunun nasıl değiştiğini şahit oldukları dönem için anılarıyla harmanlayarak anlatmakta, daha önceki dönemleri ise yine duydukları üzerinden aktarabilmektedirler. Selçuk için en özel alanlardan biri, yukarıda da referans verilen Carpuza Cafe olmuştur. Bu kafenin 1800 'lü yılların sonunda bir mühendise verildiği, sonrasında bir otele dönüştüğü, ardından bir doktora verildiği ve en son olarak kafeye dönüştüğü aktarılmıştır. Her anlatım sırasında mekan kullanımına dair de ayrıntılar verilebilmiştir. İznik kentinde de aynı durum kent için en önemli kentsel mekan olan göl için geçerlidir. Kartografik yeniden çizim ile gölün sınırlarının nasıl değiştiği, yapıların bu sınırlara ne kadar yaklaştığı anlaşılabilirken, rehberli gezi gölün kullanımının nasıl dönüştüğüne dair bir bilgiyi bize sunabilmiştir.

Yine İznik kentinden bir örnek olarak konut alanlarının dönüşümü verilebilmektedir. Kartografik yeniden çizim ile yıllar içinde konut alanlarının nerelerde yoğunlaştığı görülebilmiş, ancak rehberli gezi bu konutların eskiden nasıl mekânlar olduğunu koku, görme gibi farklı duyuları da harekete geçirerek bize gösterebilmiştir.

"Eskiden bizim evlerimiz kerpiç evlerdi. Ve beyaz badana veya çividi boya. Ve her Iznik evi bahçeliydi. Ama bahçeler evin önünde bulunmazdı, arkasında bulunurdu daha çok. Bu bahçelerde çeşit çeşit çiçekler vardı. Bu bahçelere girdiğin vakit müthiş bir koku kaplardı üzerini. Parfüm dökülmüş gibi, mis gibi kokardı. İnikli çok temizdi, o kerpiç evlerde pırıl pırıl yaşıyorlardı. Çiçeksiz ev yoktu. Her evlerin bahçelerinde hakiki Iznikli nar ağacı vardır.".
İznik'ten de Şakir Bey, bir küçük kent parçası üzerindeki bütün değişiklikleri çok katmanlı olarak anlatmaktadır. Hem depremin hangi yılda olduğundan, hem İznik'in en zengin ailesinin zamanında hangi işi yaptığından bahsetmekte, hem de Atatürk'ün zamanında gelip burada çay içtiğini anlatmaktadır:

Hem bulvarın isminin nereden geldiğini hem kentin Almanya'da bir kardeş şehri olduğunu, hem de doğal yapısını, geçmişteki gündelik alışkanlıkları aynı anda aktarmıştr. Bu farklı katmanlar aynı zamanda ulusal, uluslararası ve yerel ölçekleri de içerebilmektedir (Şekil 14).

Kartografik yeniden çizim yöntemi ile büyük bölgelerin ya da yapı adalarının nasıl değiştiği anlaşılırken, rehberli gezi fonksiyon dönüşümlerini vermektedir.

\section{Sonuç}

Araştırmada temelde iki farklı yöntem kullanılmış ve bu makale boyunca bu yöntemlerden rehberli gezi ile ortaya konan sonuçlara odaklanılmış, yöntemin tanıtımı ile bulguları ortaya koyarken yöntemin hangi konularda avantaj sağladığı vurgulanmıştır. Rehberli gezilerin Selçuk ve İznik kentlerinin değişimine dair temelde niteliksel bilginin somut fiziksel mekân ile birleştirilmesini doğrudan mümkün kılabildiği, böylece kartografik yeniden çizim yöntemi ile saptanan değişimlerin neden ve nasıl gerçekleştiğini açıklamaya yardımcı olabildiği görülmüştür.

Selçuk ve İznik kentlerinin ikisinde de, sınırların, özellikle büyük mekânsal parçaların değişimindeki en büyük etkilerden birinin doğal alanlardaki değişim olduğu kartografik çizim ile ortaya konmuştur. Bunun en çarpıcı örneği Selçuk araştırmasında karşımıza çıkmış, rehberler bu dönüşümün nasıl gerçekleştiğini çok net aktarmışlardır. Selçuk kentinin güneyinde kalan ve geçmişte sıtma hastalığı yaratan meyve bahçelerinin bataklığı ıslah etmek için oluşturulduğu, sonrasında bataklık kendiliğinden kurumaya başladığında ise o bölgenin yavaş yavaş yerleşime açıldığı, bunun da gecekondu önleme bölgesi ilanıyla aynı tarihe denk gelmiş olduğu anlaşılmıştr. Yapılı çevre içerisindeki sınırlarla ilgili olarak yapılaşmanın hangi yılda nereye kadar ilerlemiş olduğu ve nasıl, neden dönüştüğü rehberler tarafindan ayrıntlı anlatılmıştır. Bununla ilgili en çarpıcı örnek ise İznik kentinde, surların dışına taşan yapılaşmanın rehberler tarafindan ayrıntlı olarak tarif edilmesidir.

Diğer yandan rehberli gezi yöntemi kentteki mekânsal değişimler üzerinden toplumsal dönüşümün okunabilmesini sağlamıştır. İznik'te gölün önemli bir sosyalleşme aracı olduğu ve bu sosyalleşme aracının aynı zamanda toplumsal yapıya ayna tutan bir tarafi bulunduğu, bu sayede gölün kullanımındaki dönüşümün bize toplumsal dönüşümü gösterdiği, böylelikle İznik kentinin muhafazakarlaşma emareleri gösterdiği ortaya çıkabilmiştir. Selçuk kentinde ise özellikle Efes'in daha korumacı bir yaklaşımla kentten daha 
keskin sınırlarla ayrımasının toplumsal değişimi de beraberinde getirdiği rehberli geziler sayesinde saptanmıştır.

Üçüncü olarak, kamusal mekanların nasıl dönüştükleri hakkındaki bilgi temel olarak rehberli gezi yönteminden gelmiştir. Çarpıcı olarak karşımıza çıkan, iki kentte de kamusal mekânların eski festival ve panayırlarla ilişkilendirildiği ve bütün anlattların bu eski aktiviteler üzerinden şekillendiğidir. Böylelikle kentte ortak olarak gerçekleştirilen eğlence faaliyetlerinin başlı başına kamusal mekan oluşturma kapasitesi olduğu, bu oluşan mekanların kentliler tarafindan daha çok benimsendiği ve daha çok hatırlandığı, ortak faaliyetlerin ortadan kalkmasıyla birlikte mekânla kurulan bağın da kuvvetini kaybettiği ortaya çıkmıştır.

Dördüncü olarak, tek bir görüşme ile farklı temalar altında bilgiye ulaşmayı sağlaması açısından rehberli gezinin avantajlı bir yöntem olduğu anlaşılmıştır. Rehberli gezi araştırması bir yandan niteliksel bir veriyi görsel, işitsel, dokunsal ve sözel olarak çok katmanlı biçimde toplarken, diğer yandan somut mekânla ilişki kurup bütün bu niteliksel bilgiyi doğrudan haritalar üzerine işlemeyi sağlamaktadır. Katılımcı tarafının getirdiği avantajların yanı sıra, fiziksel mekân ve algısal mekânın birleştiği önemli bir yöntem olarak karşımıza çıkmaktadır. Şehircilik araştırmalarında çoğu zaman veriler ekonomi, toplumsal, ekoloji gibi farkIı tematik başlıklar altında, farklı yöntemlerle toplanırken rehberli gezi, tek bir yöntemle çok katmanlı bilgi toplamayı olanaklı kılmakta, böylelikle kentin çapraz okunabilmesini sağlamaktadır. Araşttrma sürecinde rehberler, tek bir konuyu anlatırken, farklı ölçekler ve katmanlar arasında gidip gelmektedirler. Yürüyüş sırasında karşılaşılan bir binanın önemi, ülke ölçeğinde yaşanan bir siyasi olaya, bir kişiye, bir dönem yapılmış olan imar planına ya da o kentteki bir festivale bağlanarak anlatılmakta, uzun sürede kurulabilecek bir bağlantının kolaylıkla anlaşılabilmesini mümkün kılmaktadır.

Son olarak rehberli gezi yöntemi kentlerin nasıl değiştiğini araşttrırken, kartografik yeniden çizim ile elde edemeyeceğimiz kadar küçük ayrıntıları ve özellikle de kent içi kullanımlardaki değişimleri saptamak konusunda kullanılabilmesi açısından avantajlıdır. Binalar, sokak ve kaldırımlar ayrıntılı biçimde irdelenebilmiştir. Selçuk kentinde Carpuza kafenin 1800'lü yıllardan günümüze geçirmiş olduğu dönüşümün ayrıntılı olarak anlatılması buna örnektir. Kentliler, özellikle bu bina gibi hayatlarına çok değen, çok fazla karşılaştkkları ve gündelik hayatları içerisinde zamanlarının bir kısmını geçirebildikleri binaları daha iyi takip etmekte ve o binalarla ilgili ayrıntlı bilgiler sunabilmektedirler.

Bu temel sonuçlara ek olarak rehberli gezi yöntemi, kuşaklara ve cinsiyete göre de yaşayanların mekana ilişkin algıları ve anlatılarının da değiştiğini hassas bir şekilde tespit eder ve bu tespit sayesinde kentin dönüşümünü farklı açılardan incelemeyi mümkün kılar.
Sonuç olarak rehberli geziler, bir kentle ilk karşılaşmanın ve o kente dair sorunları, potansiyelleri belirleyebilmek için derinleşilebilecek ilk bulguları yakalamanın en hızlı yollarından biri olarak düşünülebilir. Mekân ve toplumun anlatılarını harita üzerinde birleştirerek doğrudan çaprazlama bilgiler sunabilmesi, belirli sorunsallar temelinde mekâna müdahaleye dair karar vermek için kolaylaştırıcı olabilecektir. Dolayısıyla rehberli gezi, nicel yöntemlerle toplanan bilginin ardındakileri aramak, neden ve nasıl sorularına cevap vermek için şehircilik çalışmalarında çok önemli, tamamlayıcı bir nitel yöntem olarak kullanılabilir.

\section{Kaynaklar}

Anderson, J. 2004. Talking Whilst Walking: A Geographical Archaeology Of Knowledge. Area, 36, 254-261.

Bomfim, Z. A. C. \& Urrutia, E. P. 2015. Affective Dimension in Cognitive Maps Of Barcelona And São Paulo. International Journal Of Psychology, 40, 37-50.

Borda, O. F. 2001. Participatory Research In Social Theory: Origins And Challenges. In: Reason, P. \& Bradbury, H. (Eds.) Handbook Of Action Research. London: Sage Publication.

Brydon-Miller, M. 1997. Participatory Action Research: Psichology And Social Change. Journal Of Social Issues, 53, 657-666.

Carpiano, R. 2009. Come Take A Walk With Me: The"Go-Along" Interview As A Novel Method For Studyingt He Implications Of Place For Health And Well-Being. Health And Place, 15, 263-272.

Deleuze, G. 2004. Proust Ve Göstergeler, İstanbul, Kabalcı Yayınları.

Denzin, N. K. \& Lıncoln, Y. S. 2011. The Sage Handbook Of Qualitative Research, Thousand Oaks, Sage.

Emerson, R. M. 2001. Contemporary Field Research : Perspectives And Formulations, Prospect Heights, Ill., Waveland Press.

Finchman, B., Mcguıness, M. \& Murray, L. (Eds.) 2010b. Mobile Methodologies, Great Britain: Palgrave Macmillan.

Fuller, D. \& Kıtchın, R. Geography And The Participatory Turn. International Geographical Union, 2004 Glasgow.

Gieseking, J. J. 2013. Where We Go From Here: The Mental Sketch Mapping Method And Its Analytic Components. Qualitative Inqueries, 19, 712-724.

Haldrup, M. 2011. Choreographies Of Leisure Mobilities. In: Buscher, M., Urry, J. \& Witchger, K. (Eds.) Mobile Methods. Usa And Canada: Routledge.

Hall, B. 1984. Research, Commitment And Action: The Role Of Participatory Resarch. International Review Of Education 30.

Ingold, T. \& Lee, J. 2008. Ways Of Walking: Ethnography And Practice On Foot, London, Ashgate Pub.

Irby, D., Mawhınney, L. \& Thomas, K. 2013. Re-Examining Participatory Research In Dropout Prevention Planning in Urban Communities. Educational Action Research, 21, 267-283.

Jones, P., Bunce, G., James, E., Gıbbs, H. \& Rıcketts, J. H. 2008. Exploring Space And Place With Walking Interviews. Journal Of Research Practice, 4.

Kusenbach, M. 2003. The Go-Along As Ethnografic Research Tool. Ethnography, 4.

Kusenbach, M. 2006. Patterns Of Neighboring: Practicing Community İn The Parochial Realm. Symbolic Interaction, 29, 279306. 
Law, J. \& Urry, J. 2004. Enacting The Social. Economy And Society, 33, 390-410.

Layeb, S. Commented Walk, Segmented Walk: An Exploratory Study On The Relationship Between Urban Space And Sound Stress. Invisible Places, 2014 Viseu, Portugal.

Lewin, K. 1946. Action Research And Minority Problems. Journal Of Social Issues, 2, 34-47.

Lynch, K. 2010. Kent İMges, İstanbul, Türkiye İş Bankası Yayınları.

Mansyur, C. L., Jeng, H. A., Holloman, E. \& Debrew, L. 2016. Using Community-Based Participatory Research To Identify Environmental Justice Issues in An Inner-City Community And Inform Urban Planning. Family And Community Health, 39, 169-177.

Mcintry, A., Chatzopoulos, N., Polıt, A. \& Roz, J. 2007. Participatory Action Research: Collective Reflections On Gender, Culture, And Language. Teaching And Teacher Education, 23, 748-756.

Miaux, S., Drouın, L., Morency, P., Paquın, S., Gauvın, L. \& Jacquemın, C. 2010. Making The Narrative Walk-in-Real-Time Methodology Relevant For Public Health Intervention: Towards An Integrative Approach. Health And Place, 16, 1166-1173.

Milgram, S. \& Jodelet, D. 1976. Psychological Maps Of Paris. In: Proshansky, H. M. (Ed.) Environmental Psychology: People And Their Physical Settings. New York: Holt, Rinekart And Winston.

Murray, L. 2010. Contextualising And Mobilising Research. In: Fınchman, B., Mcguıness, M. \& Murray, L. (Eds.) Mobile Methodologies. Great Britain: Palgrave Macmillan.

Önen, S. 2016. Kenti Yürüyerek Keşfetmenin Sosyolojisi İdealkent, 18.
Petiteau, J.-Y. 2006a. La Méthode Des Itinéraires Ou La Mémoire Involontaire. In: Berque Augustin, B. P., De Bıase Alessıa, Loubes Jean-Paul Et Petteau Jean-Yves. (Ed.) Colloque Habiter Dans Sa Poétique Première,. Cerisy La Salle.

Petiteau, J. Y. La Méthode Des Itinéraires Ou La Mémoire Involontaire. In: Jean-Yves., vd., Ed. Colloque Habiter Dans Sa Poétique Première, 2006b Cerisy-La-Salle. 16.

Petiteau, J. Y. \& Pasquier, E. 2001. La MéThode Des ItinéRaires : RéCits Et Parcours. In: MıchèLe Grosjean, J.-P. T. (Ed.) L'espace Urbain En MéThodes. Marseille: ParenthèSes.

Ross, N., Holland, S. \& Ronal, E. 2009. Moving Stories: Using Mobile Methods. Qualitative Research, 9.

Salt, E. (2017). Kültürel Peyzajların Korunması ve Sürdürülebilirliği: İznik Kenti Örneği, Mimar Sinan Güzel Sanatlar Üniversitesi Mimarlık Fakültesi Şehir ve Bölge Planlama Bölümü, Lisans Bitirme Ödevi, İstanbul.

Thibaud, J. P. 2001. La Méthode Des Parcours Commentés. L'espace Urbain En Méthodes. Marseille: Parentèses.

Urry, J. 2000. Sociology Beyond Societies: Mobilities For The Twenty First Century, London, Routledge.

Yeşil, S. Ş. 2016. Psikocoğrafya ve Bir Şehir Gezgininin Anıları. Monograf, 5, 124-149.

Yücel, S.D \& Aksümer, G. 2018. Urban Mophological Change in the Case of Selçuk, Turkey: Mixed-Methods Approach. European Planning Studies, vol 27 issue1. Pp: 126-159.

Yücel, S.D, Aksümer, G., Seçer, S. 2018. Kent Morfolojisindeki Değişimin Saptanmasında Farklı Metodoloji Arayışı: Bursa İznik Örneği. Mimar Sinan GSÜ Bilimsel Araştırma Projeleri Birimi. ProjeNo:2016/05. 